Науковий вісник Дьвівського націонадьного університету ветеринарної медицини та біотехнодогій імені С.3. Гжицького

\author{
Scientific Messenger of Lviv National University \\ of Veterinary Medicine and Biotechnologies
}

\title{
The destructive effect of strong concentrations of orthophosphate acid in an acid detergent disinfectant on elements of milking equipment made of stainless steel and aluminum
}

M.M. Verkholiuk, R.A. Pelenio

Stepan Gzhytskyi National University of Veterinary Medicine and Biotechnologies Lviv, Ukraine

Article info

Received 12.02.2018

Received in revised form 23.03.2018

Accepted 26.03.2018

Stepan Gzhytskyi National University of Veterinary Medicine and Biotechnologies Lviv, Pekarska str., 50, Lviv, 79010, Ukraine.

Tel.: +38-097-466-86-32

E-mail:verholuk@ukr.net
Verkholiuk, M.M., \& Pelenio, R.A. (2018). The destructive effect of strong concentrations of orthophosphate acid in an acid detergent disinfectant on elements of milking equipment made of stainless steel and aluminum. Scientific Messenger of Lviv National University of Veterinary Medicine and Biotechnologies. 20(87), 74-77. doi: 10.15421/nvlvet8715

A huge part of the milking equipment and milk dishes are made of stainless steel and aluminum. Under certain conditions, the influence of such factors as the atmosphere, water, milk, and chemical agents leads to the destruction of metal working surfaces of the milking equipment, resulting in a shorter period of their exploitation. On damaged sites the milk remains are left, that is actually a good nutrient medium, resulting in the creation of conditions for the active development of the microflora. As a result, the following process leads to a marked reduction in disinfectant effect when sanitized. The object of this work was to investigate the influence of various concentrations of orthophosphate acid in an acid detergent disinfectant on the elements of the milking equipment made of stainless steel and aluminum. Accordingly, the result of the conducted research showed that the orthophosphate acid of all four experimental concentrations $(20,25,30,35 \%)$ in the acid detergent showed a slight destructive effect on stainless steel and was within the standard of corrosion value up to $2 \mathrm{~g} / \mathrm{m}^{2} /$ year. The increase in the concentration of orthophosphate acid caused a growth in the amount of destruction of stainless steel, which was the highest in the concentration of $35 \%$ and amounted to $0.326 \mathrm{~g} / \mathrm{m}^{2} /$ year. The rate of destruction of stainless steel was in the range from $0.895 \pm 0.0036$ to $1.712 \pm 0.0031 \mathrm{mg} / \mathrm{m}^{2} / \mathrm{hour}$ and was significantly lower than the norm, which is up to $6.0 \mathrm{mg} / \mathrm{m}^{2}-y e a r$. The magnitude of the destructive action of 20, 25, 30,35\% of the concentration of orthophosphoric acid in an acid mist and disinfectant on the plates of aluminum was higher than the norm, respectively, at 2.42, 2.88, 3.09 and 3.60 times, and the rate of destruction - respectively, at 2.17,2.63, 2.82 and 3.28 times. Therefore, the addition of a nitric acid ammonium inhibitor in the experimental variants of acidic detergent disinfectant resulted in a decrease in the magnitude of the destruction of aluminum. The results were higher than the norm but were significantly lower $(P \leq 0.05)$ compared to control, which used «Ecocid», an acid concentration of $30 \%$.

Key words: milk dishes, milking equipment, destruction, corrosion, orthophosphate acid, stainless steel, aluminum, detergent disinfectant.

\section{Руйнівна дія різної концентрації ортофосфатної кислоти в кислотному мийно-дезінфікуючому засобі на елементи доїльного устаткування, виготовлених із нержавіючої сталі та алюмінію}

\author{
М.М. Верхолюк, Р.А. Пеленьо
}

Львівський національний університет ветеринарної медицини та біотехнологій імені С.3. Гжицького, м. Львів, 79010, Україна

Значна частина доїльного устаткування та молочний посуд виготовлені із нержавіючої сталі та алюмінію. За певних умов вплив таких чинників, як атмосфера, вода, молоко, хімічні засоби зумовлює руйнування металевих робочих поверхонь дойльного обладнання, в результаті чого скорочується термін їх експлуатації. На пошкоджених ділянках затримуються залишки молока, яке є добрим поживним середовищем, внаслідок чого створюються умови для активного розвитку мікрофлори. В свою чергу ие призводить до помітного зменшення дезінфікуючого ефекту при санітарній обробці. Метою роботи було дослідити вплив орто- 
фосфатної кислоти різної концентрації у кислотному мийно-дезінфікуючому засобі на елементи доӥльного обладнання, виготовлених із нержавіючої сталі та алюмінію. В результаті проведених досліджень встановлено, щуо ортофосфатна кислота усіх чотирьох дослідних концентрачій $(20,25,30,35 \%)$ у кислотному мийно-дезінфікуючому засобі проявляла незначну руйнівну дію на нержавіючу сталь $і$ знаходилася в межах нормативу величини корозї, який становить до 2 г/м²/рік. 3більшення концентрації ортофосфатної кислоти зумовлювало зростання величини руйнування нержавіючої сталі, яка була найвищою за кониентрації 35\% $i$ становила 0,326 г/м²/рік. Швидкість руйнування нержавіючої сталі знаходилася в межах від $0,895 \pm 0,0036$ до $1,712 \pm$

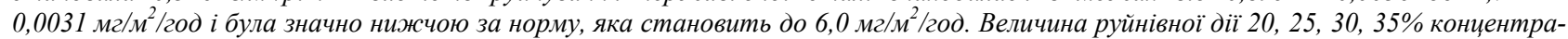
ції ортофосфатної кислоти у кислотному мийно-дезінфікуючому засобі на пластинки алюмінію була більшою за норму відповідно у 2,42, 2,88, 3,09 і 3,60 раза, а швидкість руйнування - відповідно у 2,17, 2,63, 2,82 і 3,28 раза. Додавання інгібітора амонію азотнокислого у дослідні варіанти кислотного мийно-дезінфікуючого засобу призводило до зменшення величини руйнування алюмінію. Одержані дані були вищі за норму, але вірогідно нижчі $(P \leq 0,05)$ порівняно з контролем, в якості якого використовували засіб «Ecocid», концентрація кислоти у якому $30 \%$.

Ключові слова: молочний посуд, доӥльне устаткування, руйнування, корозія, ортофосфатна кислота, нержавіюча сталь, алюміній, мийно-дезінфікуючий розчин.

\section{Вступ}

Великі молочно-товарні ферми для доїння корів використовують доїльні зали, молокопроводи, які виготовлені 3 нержавіючої сталі (Sundberg et al., 2012). Малі господарства, молочні кооперативи та особисті селянські господарства доїння корів проводять переносними доїльними апаратами вітчизняного i закордонного виробництва (Sycheva and Trubina, 2014). У закордонних апаратах, таких як «DeLavalMMUBosio», «Melasty» та інші, усі комплектуючі виготовлені з харчової нержавіючої сталі, а у вітчизняних «Дамілк АІД-1», «УІД-10», «Імпульс пбк-4», «Доярочка», «Бурьонка-1», «Велес-10», «МДУ-5» та інших молочний бідон та колектор виготовлені з алюмінію (Kukhtyn et al., 2008).

За певних умов вплив таких чинників, як атмосфера, вода, молоко, хімічні засоби зумовлює руйнування металевих робочих поверхонь доїльного обладнання, в результаті чого скорочується термін їх експлуатації (Kryvokhyzha, 2008). На пошкоджених ділянках затримуються залишки молока, яке є добрим поживним середовищем, внаслідок чого створюються умови для активного розвитку мікрофлори. Своєю чергою це призводить до помітного зменшення дезінфікуючого ефекту при санітарній обробці (Gilbert, 1982; Kovalenko and Nedosiekov, 2011; Kovalenko et al., 2016; Horyuk et al., 2016).

Використання комбінованих мийно-дезінфікуючих засобів дозволяє поєднати процеси миття і дезінфекції доїльного устаткування та молочного інвентаря. Однак такі засоби повинні відповідати певним вимогам, а саме: бути безбарвними, без запаху, добре розчинятися у воді, легко та повністю змиватися водою, не подразнювати шкіру рук працівників і не руйнувати матеріали, з яких виготовлені деталі доїльного устаткування (Reus, 2003; Palii and Synytsia, 2016; Kondrasii et al., 2017). При довготривалому контакті з металевими поверхнями доїльного устаткування та молочного інвентаря кислотні мийно-дезінфікуючі засоби можуть викликати їх корозію (Motkaliuk et al., 2014; Salata, 2016).

Метою роботи було дослідити вплив ортофосфатної кислоти різної концентрації у кислотному мийнодезінфікуючому засобі на елементи доїльного обладнання, виготовлені з нержавіючої сталі та алюмінію.

\section{Матеріали і методи досліджень}

Дослідження руйнівної дії різних концентрацій ортофосфосфатної кислоти у кислотному мийнодезінфікуючому розчині проводили згідно з методичними рекомендаціями «Оцінка придатності та ефективності мийних, дезінфікуючих i мийнодезінфікуючих засобів для санітарної обробки доїльного устаткування та молочного інвентарю» (Perkii, 2012). Матеріалом для дослідження були пластинки із нержавіючої сталі та алюмінію. Дослідження руйнівної дії ортофосфосфатної кислоти на пластинки із нержавіючої сталі тривало 15 діб (365 год), а на пластинки із алюмінію - 8 діб (182,5 год). Цей час відповідає максимальній тривалості процесу миття різного виду доїльного устаткування та молочного інвентарю протягом року. Об'єм робочого розчину брали з розрахунку $20 \mathrm{мл} / \mathrm{cm}^{2}$ площі тест-пластинки. У кожній концентрації розчину використовували по 5 пластинок нержавіючої сталі та алюмінію розміром $50 \times 20 \times 1$ мм.

Одержані результати піддавали статистичній обробці, яку проводили методом варіаційної статистики 3 визначенням середніх значень величин і середньої похибки. Вірогідність відмінностей між середніми значеннями під час проведення аналізу оцінювали, використовуючи критерії Стьюдента (t). Відмінність між величинами вважали вірогідною, коли ймовірність різниці становила $\mathrm{P} \leq 0,05$.

\section{Результати та їх обговорення}

Результати дії різних концентрацій ортофосфатної кислоти у кислотному мийно-дезінфікуючому засобі на елементи доїльного устаткування 3 нержавіючої сталі наведено у табл. 1.

Як видно із даних таблиці, ортофосфатна кислота усіх чотирьох дослідних концентрацій у кислотному мийно-дезінфікуючому засобі проявляла незначну руйнівну дію на нержавіючу сталь і в межах нормативу величини корозії, який становить до 2 г/м²/piк.

За концентрації ортофосфатної кислоти $20 \%$ величина руйнування нержавіючої сталі становила $0,326 \pm$ 0,0002 г $/ \mathrm{m}^{2} /$ рік, що в 1,61 раза більше порівняно із контролем. Збільшення концентрації кислоти до 25 і $30 \%$ зумовлювало зростання величини руйнування відповідно у 1,21 ( $\mathrm{P} \leq 0,05)$ i 1,71 раза $(\mathrm{P} \leq 0,01)$ порівняно із контролем та в 1,24 i 1,70 раза порівняно із 
$20 \%$ концентрацією кислоти. За концентрації 35\% ортофосфатної кислоти у засобі величина руйнування нержавіючої сталі становила 0,326 г/ $\mathrm{m}^{2} /$ piк і була більшою у 1,9 раза $(\mathrm{P} \leq 0,001)$, порівняно із результатом, одержаним за 20\% концентрації кислоти.

\section{Таблиця 1}

Руйнівна дія різної концентрації ортофосфатної кислоти $0,5 \%$ розчину кислотного мийно-дезінфікуючого засобу на нержавіючу сталь, $\mathrm{M} \pm \mathrm{m}, \mathrm{n}=5$

\begin{tabular}{|c|c|c|}
\hline $\begin{array}{c}\text { Концентрація } \\
\text { ортофосфатної } \\
\text { кислоти, \% }\end{array}$ & $\begin{array}{c}\text { Величина руйну- } \\
\text { вання, } \\
\text { Г/м²/рік }\end{array}$ & $\begin{array}{c}\text { Швидкість } \\
\text { руйнування, } \\
\text { мг/м²/год }\end{array}$ \\
\hline 20 & $0,326 \pm 0,0002$ & $0,895 \pm 0,0036$ \\
\hline 25 & $0,405 \pm 0,0010 *$ & $1,111 \pm 0,0011^{*}$ \\
\hline 30 & $0,555 \pm 0,0071 * *$ & $1,520 \pm 0,0025 * *$ \\
\hline 35 & $0,625 \pm 0,0321 * * *$ & $1,712 \pm 0,0031 * * *$ \\
\hline $\begin{array}{c}\text { Контроль } \\
\text { (дистильована } \\
\text { вода) }\end{array}$ & $0,202 \pm 0,0001$ & $0,555 \pm 0,0035$ \\
\hline
\end{tabular}

Примітки: норма величини корозії $\leq 2,0$ г/м² $/$ рік; швидкість корозії $\leq 6,0 \mathrm{Mг} / \mathrm{M}^{2} /$ год

Швидкість руйнування нержавіючої сталі, як і величина руйнування, за усіх досліджуваних концентрацій ортофосфатної кислоти знаходилася в межах від $0,895 \pm 0,0036$ до $1,712 \pm 0,0031 \mathrm{мг} / \mathrm{m}^{2} /$ год і була значно нижчою за норму, яка становить $\leq 6,0 \mathrm{мг} / \mathrm{m}^{2} /$ год.

На підставі одержаних результатів нами встановлено, що всі дослідні концентрації ортофосфатної кислоти відповідають нормативам корозійної дії щодо нержавіючої сталі і можуть бути використані для створення нового кислотного засобу для санітарної обробки доїльного устаткування і молочного інвентарю виготовленого із нержавіючої сталі.

У табл. 2 наведено результати руйнівної дії різної концентрації ортофосфатної кислоти $0,5 \%$ розчину кислотного мийно-дезінфікуючого засобу на алюміній. Ортофосфатна кислота проявляли високу корозійну дію на алюміній навіть за найнижчої ії концентрації у кислотному мийно-дезінфікуючому розчині.

\section{Таблиця 2}

Руйнівна дія різної концентрації ортофосфатної кислоти $0,5 \%$ розчину кислотного мийно-дезінфікуючого засобу на алюміній, $\mathrm{M} \pm \mathrm{m}, \mathrm{n}=5$

\begin{tabular}{|c|c|c|}
\hline $\begin{array}{c}\text { Концентрація } \\
\text { ортофосфатної } \\
\text { кислоти, \% }\end{array}$ & 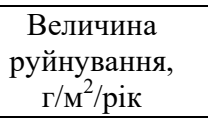 & $\begin{array}{c}\text { Швидкість руй- } \\
\text { нування, } \\
\text { мг/м²/год }\end{array}$ \\
\hline 20 & $4,84 \pm 0,444$ & $26,14 \pm 2,945$ \\
\hline 25 & $5,76 \pm 0,282$ & $31,60 \pm 1,548$ \\
\hline 30 & $6,18 \pm 0,345 *$ & $33,88 \pm 1,893$ \\
\hline 35 & $7,20 \pm 0,509 *$ & $39,46 \pm 2,793 *$ \\
\hline $\begin{array}{c}\text { Контроль } \\
\text { (дистильована } \\
\text { вода) }\end{array}$ & $0,20 \pm 0,003$ & $1,09 \pm 0,035$ \\
\hline
\end{tabular}

Примітки: норма величини корозії $\leq 2,0$ г/ $\mathrm{m}^{2} /$ рік; швидкість корозії $\leq 12,0 \mathrm{мг} / \mathrm{m}^{2} /$ год

Величина руйнівної дії 20\% концентрації ортофосфатної кислоти у кислотному мийно-дезінфікуючому засобі на пластинки алюмінію становила 4,84 \pm

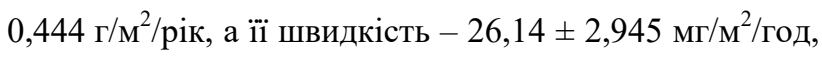
що відповідно у 2,42 і 2,17 раза було більшим за показники норми. Збільшення концентрації кислоти на $5,0 \%$ зумовило зростання, порівняно із нормативними показниками, величини і швидкості руйнування алюмінієвих пластинок відповідно у 2,88 і 2,63 раза. Вірогідно вищою, порівняно 3 контролем, за концентрації кислоти $30 \%$ була величина руйнування алюмінію, яка становила $6,18 \pm 0,345 \Gamma / \mathrm{m}^{2} /$ рік $(\mathrm{P} \leq 0,05)$, тимчасом як за концентрації ортофосфатної кислоти 35\% вірогідно вищими $(\mathrm{P} \leq 0,05)$ була як величина, так $\mathrm{i}$ швидкість руйнування і їх величини становили відпо-

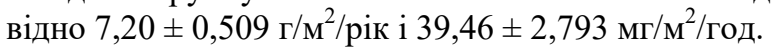

На підставі одержаних результатів встановлено, що розчини дослідних варіантів кислотних засобів проявляли високу корозійну активність на алюміній і значно перевищували визначені нормативи.

Враховуючи попередньо проведені дослідження руйнування молочного каменю дослідними зразками ортофосфорної кислоти найбільш оптимальним та ефективним для санітарної обробки обладнання є 30\% вміст ортофосфорної кислоти у дослідному кислотному мийно-дезінфікуючому засобі.

У таблиці 3 наведені результати досліджень корозійної дії на алюміній $0,5 \%$ кислотного мийнодезінфікуючого розчину із концентрацією ортофосфатної кислоти 30\% та різним вмістом інгібітора - амонію азотнокислого.

\section{Таблиця 3}

Руйнівна дія $0,5 \%$ кислотного мийно-дезінфікуючого розчину із концентрацією ортофосфатної кислоти 30\% та різним вмістом інгібітора амонію азотнокислого на алюміній, $\mathrm{M} \pm \mathrm{m}, \mathrm{n}=5$

\begin{tabular}{|c|c|c|}
\hline $\begin{array}{l}\text { Концентрація } \\
\text { інгібітора, \% }\end{array}$ & 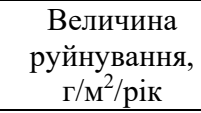 & $\begin{array}{c}\text { Швидкість } \\
\text { руйнування, } \\
\text { мг/м²/год }\end{array}$ \\
\hline 3,0 & $4,01 \pm 0,084$ & $21,98 \pm 0,465$ \\
\hline 4,0 & $3,09 \pm 0,147$ & $16,96 \pm 0,809$ \\
\hline 5,0 & $2,43 \pm 0,079 *$ & $13,32 \pm 0,437 *$ \\
\hline 6,0 & $2,14 \pm 0,159 *$ & $11,77 \pm 0,875 *$ \\
\hline $\begin{array}{c}\text { Контроль: засіб } \\
\text { «Есо сіd» }\end{array}$ & $5,23 \pm 0,614$ & $28,65 \pm 1,253$ \\
\hline
\end{tabular}

Примітки: норма величини корозії $\leq 2,0$ г/ $/ \mathrm{m}^{2} /$ рік; швидкості корозії $\leq 12,0$ мг $/ \mathrm{M}^{2} /$ год.; * $-\mathrm{P} \leq 0,05$

Встановлено, що додавання інгібітора амонію азотнокислого у дослідний варіант кислотного мийнодезінфікуючого засобу призводило до зменшення величини руйнування алюмінію. За вмісту інгібітора 3,0\% руйнівна дія ортофосфатної кислоти на алюміній зменшувалася у 1,30 раза, за $4,0 \%$ - у 1,69 раза, за 5\% - у 2,15 раза $(\mathrm{P} \leq 0,05)$ і за концентрації $6,0 \%$ 2,44 раза $(\mathrm{P} \leq 0,05)$. Додавання 3,0 і 4,0\% інгібітора знизило швидкість руйнування алюмінію, порівняно із контролем, відповідно у 1,30, 1,68 раза, а за його концентрації 5,0 і 6,0\% відповідно у 2,15 і 2,43 раза, і ці різниці були вірогідними $(\mathrm{P} \leq 0,05)$.

Враховуючи, що вміст інгібіторів корозії у кислотних мийно-дезінфікуючих засобах в основному становить 4-5\% і найбільш ефективними в наших дослідах виявились концентрації інгібітора 5 і 6\%, оптима- 
льним в нашому випадку буде менша концентрація амонію азотнокислого у складі дослідного варіанту кислотного мийно-дезинфікуючого засобу, а саме: $5 \%$.

\section{Висновки}

1. Використання ортофосфатної кислоти у концентраціях 20, 25, 30 та 35\% спричиняло руйнівну дію на пластинки 3 нержавіючої сталі відповідно від 0,326 до 0,625 г/м²/piк за швидкості руйнації відповідно від 0,895 до 1,1712 мг/м²/год, що було у межах норми

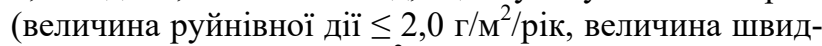
кості руйнації $\leq 12,0 \mathrm{M \Gamma} / \mathrm{M}^{2} /$ год.

2. Використання ортофосфатної кислоти у концентраціях 20, 25, 30 та 35\% спричиняло руйнівну дію на пластинки 3 алюмінію відповідно від 4,84 до 7,2 г/м² до $39,46 \mathrm{мг} / \mathrm{m}^{2} /$ год, що перевищувало нормативні величини відповідно у 2,42 та 2,17 рази.

3. Рекомендованою концентрацією інгібітора амонію азотнокислого в кислотному мийнодезінфікуючому засобі буде 5\%, при якій вірогідно $(\mathrm{P} \leq 0,05)$ знижується величина та швидкість руйнування алюмінію порівняно із контролем у 2,15 рази.

Перспективи подальших досліджень. Планується провести дослідження впливу дослідних варіантів кислотного мийно-дезінфікуючого засобу на дійкову гуму та токсикологічні дослідження нового кислотного мийно-дезінфікуючого.

\section{References}

Gilbert, P.H. (1982). The use of detergents and sanitizers in dairy farm sanitation-an updated perspective. Journal of the South African Veterinary Association. 53(2), 103106. https://www.ncbi.nlm.nih.gov/pubmed/7120266.

Horyuk, Yu.V., Kukhtyn, M.D., Perkiy, Yu.B., Horyuk, V.V., \& Semenyuk, V.I. (2016). Identification of Enterococcus isolated from raw milk and cottage cheese «home» production and study of their sensitivity to antibiotics. Scientific Messenger LNUVMBT named after S.Z. Gzhytskyj. 18, 3(70), 44-48. doi:10.15421/nvlvet7011.

Kondrasii, L.A., Iakubchak, O.M., \& Shevchenko, L.V. (2017). An algorithm for good dairy farming practices implementation in order to obtain safety and quality raw milk. Scientific Messenger LNUVMB. 19(78), 53-57. doi:10.15421/nvlvet7811.

Kovalenko, V.L., \& Nedosiekov, V.V. (2011). Kontseptsiia rozrobky ta vykorystannia kompleksnykh dezinfektantiv dlia veterynarnoi medytsyny: monohrafiia. Kyiv: Vyd-vo TOV «NVP «Interservis» (in Ukrainian).
Kovalenko, V.L., Zagrebelnyi, A.V., Vishchur, O.I., \& Chekhun, A.I. (2016). Comparative evaluation of disinfectants with a cleaning effect by disinfection E. Coli and S. Aureus. Scientific Messenger LNUVMBT named after S.Z. Gzhytskyj. 18, 2(66), 88-91. doi:10.15421/nvlvet6619.

Kryvokhyzha, Ye.M. (2008). Koroziini vlastyvosti zasobiv dlia sanitarnoi obrobky molochnoho obladnannia. Naukovyi visnyk Lvivskoho natsionalnoho universytetu veterynarnoi medytsyny ta biotekhnolohii im. S.Z. Gzhy-tskoho. 10(2), 84-87 (in Ukrainian).

Kukhtyn, M.D., Motkaliuk,N.F., Kryvokhyzha, Ie.M., \& Rusenko, Ya.H. (2008). Porivnialna kharakterystyka zasobiv sanitarnoi obrobky doilnykh ustanovok i molochnoho obladnannia. Veterynarna biotekhnolohiia. Biuleten. 12, 121-125 (in Ukrainian).

Motkaliuk, N.F., Kryvokhyzha, Ye.M., Kryzhanivskyi, Ya.Y., \& Karpenko, M.M. (2014). Metod vyznachennia efek-tyvnosti kyslotnykh myinykh zasobiv dlia sanitarnoi obrobky doilnoho ustatkuvannia v laboratornykh umovakh. Naukovotekhnichnyi biuleten instytutu biolohii tvaryn i Derzhavnoho naukovo-doslidnoho kontrolnoho instytutu vetpreparativ ta kormovykh dobavok. 2-3(15), 295-298 (in Ukrainian).

Palii, A.P., \& Synytsia, O.V. (2016). Sanitarna obrobka doilno-molochnoho obladnannia. Visnyk KhNTUSH im. P. Vasylenka. 170, 51-55 (in Ukrainian).

Perkii, Yu.B. (2012). Otsinka prydatnosti ta efektyvnosti myinykh, dezinfikuiuchykh i myino-dezinfikuiuchykh zasobiv dlia sa-nitarnoi obrobky doilnoho ustatkuvannia ta molochnoho inventaria: metodychni rekomendatsii. Ternopilska derzhavna silskohospodarska doslidna stantsiia IKSHP NAAN (in Ukrainian).

Reus, H.R. (2003). The use of disinfectants in veterinary practice. Tides shrift digressed. 128(4), 106-109. https://www.ncbi.nlm.nih.gov/pubmed/12625156.

Salata V.Z. (2016). Corrosive action of detergent disinfectant «San active» for metal surface technology equipment of meat processing industry. Scientific Messenger LNUVMBT named after S.Z. Gzhytskyj. 18, 2(66), 157-161. doi:10.15421/nvlvet6632.

Sundberg, M., Christiansson, A., Lindahl, C., Wahlund, L., \& Birgersson, C. (2011). Cleaning effectiveness of chlorine-free detergents for use on dairy farms. Journal of Dairy Research. 78(1), 105-110. doi: 10.1017/S0022029910000762.

Sycheva, O.V., Trubina, I.A. (2014). Jekspertiza molochnogo syr'ja: uchebnoe posobie. M.-Berlin: Direkt-Media (in Russian). 